\title{
ODMOWA WYKONANIA OBOWIĄZKU PODDANIA DZIECKA SZCZEPIENIU OCHRONNEMU
}

\section{Wstęp}

Obowiązek poddania dziecka szczepieniom ochronnym jest obowiązkiem ustawowym, od którego uwolnić mogą jedynie przeciwskazania zdrowotne. Rolą szczepień ochronnych jest zapobieganie chorobom zakaźnym, kształtowanie odporności całej populacji oraz zapewnienie ochrony tym osobom, które ze względu na zdrowotne przeciwskazania nie mogą być zaszczepione lub przyjmują leki immunosupresyjne. Za realizację obowiązku szczepień ochronnych dzieci odpowiedzialni są ich przedstawiciele ustawowi oraz opiekunowie faktyczni na podstawie ustawy z dnia 5 grudnia 2008 r. o zapobieganiu oraz zwalczaniu zakażeń i chorób zakaźnych u ludzi ${ }^{1}$. Osoby przebywające na terenie Rzeczypospolitej Polskiej są obowiązane na zasadach określnych w tym akcie prawnym do poddania się szczepieniom ochronnym. W przypadku osoby nieposiadającej pełnej zdolności do czynności prawnych odpowiedzialność za poddanie obowiązkowi szczepień spoczywa na osobie sprawującej prawną pieczę nad osobą małoletnią lub bezradną albo na opiekunie faktycznym w rozumieniu art. 3 ust. 1 pkt 1 ustawy z dnia 6 listopada 2008 r. o prawach pacjenta i Rzeczniku Praw Pacjenta².

\footnotetext{
* Dr, Uniwersytet Medyczny w Lublinie; e-mail: jolapacian@gmail.com.

1 Ustawa z dnia 5 grudnia 2008 r. o zapobieganiu oraz zwalczaniu zakażeń i chorób zakaźnych u ludzi, tekst jednolity: Dz. U. z 2019 r. poz. 1239 (dalej: u.z.z.z.ch).

2 Ustawa z dnia 6 listopada 2008 r. o prawach pacjenta i Rzeczniku Praw Pacjenta, tekst jednolity: Dz. U. z 2019 r. poz. 1127 z późn. zm. (dalej: u.p.p.R.P.P.).
} 


\section{Obowiązek ustawowy poddania dziecka szczepieniu ochronnemu}

Analiza przepisów przywołanej ustawy pozwala jednoznacznie wyinterpretować normę prawną, która ustanawia obowiązek poddania dziecka szczepieniu ochronnemu, tzn. określa wszystkie istotne cechy tego obowiązku. Co więcej, norma ta określa bowiem podmiot, na którym ten obowiązek ciąży, okoliczności, w których obowiązek ten się aktualizuje oraz jego zakres. Ponadto I. Jaworska podnosi, że rodzice nie mogą odmówić zgody na poddanie dziecka szczepieniom obowiązkowym, gdy nie ma żadnych przeciwwskazań do szczepień3. Naczelny Sąd Administracyjny (NSA) orzekł, że obowiązek poddania się obowiązkowym szczepieniom ochronnym wynika z mocy przepisu prawa i nie ma podstawy prawnej do konkretyzacji w formie decyzji administracyjnej. W ocenie sądu wniosek powyższy wynika z treści art. 17 ust. 1 u.z.z.z.ch., zgodnie z którym osoby, określone na podstawie ust. 10 pkt 2 u.z.z.z.ch., są obowiązane do poddawania się szczepieniom ochronnym przeciw chorobom zakaźnym, określonym na podstawie ust. 10 pkt 1 u.z.z.z.ch . Wykonanie tego obowiązku z mocy prawa zabezpieczone jest przymusem administracyjnym oraz odpowiedzialnością regulowaną przepisami ustawy z dnia 20 maja 1971 r. - Kodeks wykroczeń5.

Co więcej, art. 17 u.z.z.z.ch stanowi, że osoby, określone na podstawie ust. 10 pkt 2 u.z.z.z.ch obowiązane do poddawania się szczepieniom ochronnym przeciw chorobom zakaźnym określonym na podstawie ust. 10 pkt 1 u.z.z.z.ch, zwanym dalej „obowiązkowymi szczepieniami ochronnymi”. Powyższe uregulowania prawne pozwalają na postawienie tezy, że ten obowiązek dotyczy wszystkich osób przebywających na terenie RP, w tym również przedstawicieli ustawowych osób małoletnich oraz opiekunów faktycznych małoletnich i bezradnych. Na tle dotychczasowego stanu prawnego w orzecznictwie jednolicie przyjmuje się, jak orzekł Wojewódzki Sąd Administracyjny (WSA) w Warszawie w wyroku z dnia

3 Zob. I. Jaworska, Odmowa zaszczepienia dziecka i jej konsekwencje prawne, „Przegląd Prawa Publicznego" 2017, nr 3, s. 60-72.

4 Zob. wyrok Naczelnego Sądu Administracyjnego z dnia 29 stycznia 2010 r., II FSK 1494/08, Centralna Baza Orzeczeń Sądów Administracyjnych (CBOSA); wyrok Wojewódzkiego Sądu Administracyjnego w Białymstoku z dnia 1 lutego 2011 r., II SA/BK 723/10, Legalis nr 339506.

5 Ustawa z dnia 20 maja 1971 r. - Kodeks wykroczeń, tekst jednolity: Dz. U. z 2019 r. poz. 821 z późn. zm. 
19 października 2016 r., że obowiązek wykonania szczepienia ochronnego wynika z art. 31 ust. 3 Konstytucji $\mathrm{RP}^{6}$, a dokładnie:

obowiązek poddania się szczepieniu ochronnemu ma silne oparcie w przepisach Konstytucji RP, a przede wszystkim art. 31 ust. 3, który stanowi, że ograniczenia w zakresie korzystania z konstytucyjnych wolności i praw mogą być ustanawiane tylko w ustawie i tylko wtedy gdy są konieczne w demokratycznym państwie dla jego bezpieczeństwa lub porządku publicznego, bądź dla ochrony środowiska, zdrowia i moralności publicznej, albo wolności i praw innych osób?

\section{Badanie kwalifikacyjne jako obowiązkowa przesłanka wykonania szczepienia ochronnego}

Dostrzegając racje leżące u podstaw stanowiska, że szczepienie ochronne jest obowiązkiem ustawowym, należy stwierdzić, że prawo do decydowania o poddaniu dziecka szczepieniu ochronnemu ma wyłącznie lekarz przeprowadzający badanie kwalifikacyjne. Po wykonaniu tego badania lekarz wydaje zaświadczenie. $W$ takim zaświadczeniu musi być wpisana data i godzina przeprowadzenia badania. Ma to istotne znaczenie z uwagi na fakt, że obowiązkowe szczepienie ochronne nie może być przeprowadzone, jeżeli od tego badania minęło więcej niż 24 godziny. Przedstawiciele ustawowi oraz opiekunowie faktyczni nie mogą również odmówić poddania dziecka badaniu kwalifikacyjnemu. Bowiem odmowa poddania dziecka badaniu poprzedzającemu wykonanie szczepienia ochronnego jest równoważna z odmową poddania się szczepieniu. Wynikające z wyżej poczynionych ustaleń twierdzenie, że szczepienie nie może być zaaplikowane bez przeprowadzenia wcześniejszego badania, należy do kluczowych dla oceny odmowy poddania dziecka obowiązkowi szczepień ochronnych. Znajduje to potwierdzenie $\mathrm{w}$ uzasadnieniu wyroku WSA w Warszawie z dnia 19 października 2016 r., w którym WSA orzekł, że o realizacji szcze-

6 Zob. K. Radlak, Ograniczenie konstytucyjnych wolności i praw obywatela a obowiazek szczepień w świetle projektu ustawy o zmianie ustawy o zapobieganiu oraz zwalczaniu zakażeń i chorób zakaźnych u ludzi oraz niektórych innych ustaw z 27.10.2017 r., „Przegląd Prawa Publicznego" 2018, nr 5, s. 27 i nast.

7 Wyrok Wojewódzkiego Sądu Administracyjnego w Warszawie z dnia 19 października 2016 r., VII SA/Wa 2539/15, LEX nr 2159949. 
pień obowiązkowych i kwalifikacji podania ich u dziecka decyduje każdorazowo lekarz, po uprzednim wykonaniu szczegółowego badania obecnego stanu zdrowia oraz zebraniu potrzebnych informacji podczas wywiadu z rodzicami, a nie rodzic, który ze względu na swoje przekonania sprzeciwia się wykonaniu szczepień ochronnych w okresach uzasadnionych medycznie i epidemiologicznie ${ }^{8}$. Co więcej WSA w Krakowie w wyroku z dnia 26 kwietnia 2012 r., orzekł, że o ile egzekucja administracyjna zmierza do wyrażenia zgody opiekuna prawnego czy faktycznego na obowiązkowe szczepienia dziecka, o tyle postępowanie to nie może być prowadzone, gdy istnieją przeciwwskazania do poddania dziecka szczepieniom. Skutkuje to tym, że mimo istnienia obowiązkowych szczepień w konkretnym przypadku obowiązek taki nie jest wymagalny z powodu istnienia przeciwwskazań do jego wykonania. Również zarzut niewymagalności obowiązku może być tym samym podniesiony jedynie skutecznie w sytuacji, gdy stan zdrowia dziecka uniemożliwia podanie mu szczepionki9.

Ponadto należy podkreślić, że zgodnie z $§ 7$ rozporządzenia Ministra Zdrowia z dnia 28 marca 2018 r. w sprawie szczepień ochronnych ${ }^{10}$ lekarskie badanie kwalifikacyjne oraz obowiązkowe szczepienia ochronne u osoby, która nie ukończyła 6 roku życia, przeprowadza się w obecności osoby, która sprawuje prawną pieczę nad tą osobą albo opiekuna faktycznego. Zaś lekarskie badanie kwalifikacyjne oraz obowiązkowe szczepienia ochronne u osoby, która ukończyła 6 rok życia, a nie osiągnęła pełnoletności, można przeprowadzić bez obecności osoby, która sprawuje prawną pieczę albo opiekuna faktycznego, po uzyskaniu ich pisemnej zgody i informacji na temat uwarunkowań zdrowotnych mogących stanowić przeciwwskazanie. Natomiast lekarskie badanie kwalifikacyjne oraz obowiązkowe szczepienia ochronne przeprowadza się indywidualnie. Tak więc ani badanie, ani szczepienie nie powinno odbywać się w obecności innych osób niż uprawnione, a opiekun dziecka powinien być obecny zarówno przy badaniu jak i szczepieniu.

Problematyczne jest określenie, które osoby można uznać za opiekunów faktycznych. Ustawa o zapobieganiu i zwalczaniu zakażeń i chorób

8 Zob. wyrok Wojewódzkiego Sądu Administracyjnego w Warszawie z dnia 19 października 2016 r., VII SA/Wa 2541, CBOSA.

9 Zob. wyrok Wojewódzkiego Sądu Administracyjnego w Krakowie z dnia 26 kwietnia 2012 r., III SA/Kr 901/11, CBOSA.

10 Rozporządzenie Ministra Zdrowia z dnia 18 sierpnia 2011 r. w sprawie obowiązkowych szczepień ochronnych, tekst jednolity: Dz. U. z 2018 r. poz. 753. 
zakaźnych u ludzi stanowi o „osobie sprawującej, bez obowiązku ustawowego, stałą opiekę nad pacjentem, który ze względu na wiek, stan zdrowia albo stan psychiczny opieki takiej wymaga". Skutkuje to tym, że osoba opiekująca się dzieckiem doraźnie - nie jest opiekunem faktycznym. Jednakże gdyby rodzice dziecka znajdowali się przez dłuższy czas za granicą, w takiej sytuacji osoby sprawujące czasową opiekę byłyby uprawnione, aby zaprowadzić dziecko na szczepienie ${ }^{11}$. Jednak inaczej wygląda sytuacja, gdy szczepieniu ma zostać poddane dziecko powyżej 6 roku życia. Wówczas obecność opiekuna nie jest wymagana, lecz konieczna jest pisemna zgoda osoby sprawującej pieczę prawną ${ }^{12}$. Oznacza to, że osoby sprawujące opiekę czasowo, a nawet samo dziecko może zgłosić się do szczepienia, posiadając uprzednią zgodę rodzica. Według tego uregulowania niedopuszczalne jest zaszczepienie dziecka bez zgody rodziców lub opiekunów prawnych ${ }^{13}$.

W sytuacji gdy wystąpi odczyn poszczepienny ${ }^{14}$ to, obowiązek poinformowania powiatowego inspektora sanitarnego ciąży na lekarzu lub felczerze $^{15}$. Ten obowiązek wynika z $\S 5$ ust. 1 rozporządzenia Ministra Zdrowia z dnia 21 grudnia 2010 r. w sprawie niepożądanych odczynów poszczepiennych oraz kryteriów ich rozpoznawania ${ }^{16}$. Niepożądany odczyn poszczepienny to niepożądany objaw chorobowy pozostający w związ$\mathrm{ku}$ czasowym z wykonanym szczepieniem ochronnym (art. 2 pkt 16 u.z.z.z.ch). Jak podnosi M. Ożóg, zgłoszeniu na podstawie obowiązujących przepisów podlega wyraźnie samo zaistnienie objawu chorobowego pozostającego w związku czasowym ze szczepieniem ochronnym, nawet jeżeli brak innych podstaw do przypisania takiemu objawowi związku ze szczepieniem, jak np. wystąpienie rumienia w miejscu, w którym do-

11 Zob. R. Kubiak, Szczepienia dzieci bez obecności rodziców, „Medycyna Praktyczna. Szczepienia" 2012, nr 2, s. 80-81.

12 Zob. A. Augustynowicz, I. Wrześniewska-Wal, Aspekty prawne obowiązkowych szczepień ochronnych u dzieci, „Pediatria Polska” 2013, t. 88, s. 122.

13 Zob. S. Gałecki, Szczepienia obowiazkowe - wolność jednostki a bezpieczeństwo społeczności, „Medycyna Praktyczna. Szczepienia” 2014, nr 3, s. 87-90.

14 Zob. K. Gajdzińska-Ożóg, M. Ożóg, Zgłaszanie niepożądanych odczynów poszczepiennych w świetle ustawy z 5 grudnia 2008 r. o zapobieganiu oraz zwalczaniu zakażeń $i$ chorób zakaźnych u ludzi, „Przegląd Prawa Publicznego” 2010, nr 6, s. 42 i nast.

15 Zob. wyrok Wojewódzkiego Sądu Administracyjnego w Warszawie z dnia 5 kwietnia 2017 r., VII SA/Wa 301/17, CBOSA.

16 Rozporządzenie Ministra Zdrowia z dnia 21 grudnia 2010 r. w sprawie niepożądanych odczynów poszczepiennych oraz kryteriów ich rozpoznawania, Dz. U. z 2010 r. Nr 254, poz. 1711. 
konano wkłucia ${ }^{17}$. W przedmiotowym rozporządzeniu do ustawy mowa jest także o przypadkach wystąpienia „ciężkiego" lub „poważnego niepożądanego odczynu poszczepiennego" (§ 7 rozporządzenia w zw. z art. 19 ust. 3 u.z.z.z.ch). Należy podkreślić jednak, że pojęcie „poważnego niepożądanego odczynu poszczepiennego" nie jest sprecyzowane w Prawie farmaceutycznym ${ }^{18}$, a jego obecność $\mathrm{w}$ rozporządzeniu nasuwa wątpliwości co do przystawalności siatki pojęciowej zastosowanej w rozporządzeniu do siatki pojęciowej tejże ustawy. Co więcej, przypadek podejrzewanego lub rozpoznanego wystąpienia niepożądanego odczynu poszczepiennego podlega zgłoszeniu do państwowego powiatowego inspektora sanitarnego właściwego dla miejsca powzięcia podejrzenia wystąpienia przypadku (art. 21 ust. 1 u.z.z.z.ch).

Naczelny Sąd Administracyjny w wyroku z dnia 1 sierpnia 2013 r. orzekł, że

obowiązek poddania się obowiązkowym szczepieniom ochronnym wynika z mocy przepisów ustawowych, nie ma zatem podstawy prawnej do jego konkretyzacji w formie decyzji administracyjnej. Wynikający z przepisów obowiązek poddania dziecka szczepieniu ochronnemu jest bezpośrednio wykonalny. Jego niedochowanie aktualizuje obowiązek wszczęcia postępowania egzekucyjnego, którego rezultatem będzie poddanie dziecka szczepieniu ochronnemu ${ }^{19}$.

\section{Konsekwencje administracyjne i karne niewykonania obowiązku szczepień ochronnych}

Niewykonanie obowiązku szczepień ochronnych skutkuje konsekwencjami administracyjnymi i karnymi. Jak podkreśla K. Radlak:

nałożenie przez ustawodawcę powszechnego obowiązku poddawania się szczepieniom ochronnym przeciw niektórym chorobom nie oznacza przymusowego wykonania szczepienia z zastosowaniem środków przymusu bezpośredniego, ale brak realizacji wykonania obowiązku szczepienia może

17 Zob. M. Ożóg, System handlu produktem leczniczym i produktami pokrewnymi. Problematyka prawna, Warszawa 2010, s. 233-234.

18 Ustawa z dnia 6 września 2001 r. - Prawo farmaceutyczne, tekst jednolity: Dz. U. z 2019 r. poz. 499 z późn. zm.

19 Wyrok Naczelnego Sądu Administracyjnego z dnia 1 sierpnia 2013 r., II OSK 745/12, CBOSA. 
powodować konsekwencje prawne wynikające z przepisów ustawy o postępowaniu egzekucyjnym w administracji w zakresie obowiązków o charakterze niepieniężnym ${ }^{20}$.

Obowiązek poddania dziecka szczepieniom ochronnym wynika z mocy przepisów ustawowych ${ }^{21}$. Zatem przyjmuje się, że nie ma konieczności wydawania decyzji administracyjnej, a niepodjęcie działań będzie miało konsekwencje prawne. Nie budzi wątpliwości, że organem uprawnionym do wszczęcia i prowadzenia takiej egzekucji jest wojewoda. Potwierdził to WSA w Poznaniu w wyroku z dnia 11 września 2013 r.:

To wojewoda jest organem właściwym do prowadzenia egzekucji obowiązków o charakterze niepieniężnym, wynikających zarówno z wydanych przez siebie rozstrzygnięć indywidualnych (decyzji, postanowień), jak i obowiązków niepieniężnych wynikających wprost z mocy przepisów prawa22.

Tak więc należy przyjąć i ponownie podkreślić, że organem uprawnionym do egzekwowania tego obowiązku jest wojewoda, który zgodnie z ustawą z dnia 17 czerwca 1966 r. o postępowaniu egzekucyjnym w administracji²3 może nałożyć karę grzywny w łącznej wysokości nawet do 50 tys. złotych. Sąd Najwyższy (SN) w wyroku z dnia 8 stycznia 2016 r. orzekł, że „obowiązek rodziców poddania dziecka obowiązkowym szczepieniom ochronnym jest obowiązkiem prawnym, od którego uwolnić mogą jedynie konkretne przeciwskazania lekarskie do szczepienia" ${ }^{24}$. Co więcej, jak słusznie twierdzi P. Daniel:

postępowanie [egzekucyjne w przedmiocie obowiązku poddania małoletniego dziecka szczepieniu ochronnemu - P.D.] powinno być kierowane do obojga rodziców, chyba że organ egzekucyjny będzie w posiadaniu dowodów, wskazujących na fakt sprawowania opieki nad małoletnim jedynie przez jednego z rodziców ${ }^{25}$.

20 K. Radlak, Ograniczenie konstytucyjnych wolności..., s. 28.

21 Zob. wyrok Sądu Najwyższego z dnia 8 stycznia 2016 r., V KK306/15, LEX nr 1963649.

${ }^{22}$ Wyrok Wojewódzkiego Sądu Administracyjnego w Poznaniu z dnia 11 września 2013 r., II SA/Po 711/13, CBOSA.

23 Ustawa z dnia 17 czerwca 1966 r. o postępowaniu egzekucyjnym w administracji, tekst jednolity: Dz. U. z 2019 r. poz. 1348 z późn. zm.

${ }^{24}$ Wyrok Sądu Najwyższego Izba Karna z dnia 8 stycznia 2016 r., V KK 306/15, LEX nr 1963649.

25 P. Daniel, Egzekucja obowiazku poddania małoletniego dziecka szczepieniu ochronnemu w orzecznictwie sądów administracyjnych, "Przegląd Prawa Publicznego” 2014, nr 4, s. 45-55. 
Sąd Najwyższy w wyroku z dnia 8 stycznia 2016 r. oraz WSA w Białymstoku w wyroku z dnia 16 kwietnia 2013 r., odnosząc się do klauzuli sumienia orzekł, że „,ustawowy obowiązek szczepień ochronnych oznacza niedopuszczalność korzystania z tzw. klauzuli sumienia, tj. uprawnienia pacjenta do odmowy poddania się świadczeniu zdrowotnemu z powołaniem się na art. 16 u.p.p.R.P.P." ${ }^{26}$ Zatem $\mathrm{z}$ uwagi na ten fakt, odpowiednie organy administracji rządowej, tj. wojewoda, mogą egzekwować ten obowiązek. Korelacja takiego obowiązku z brakiem możliwości odmowy ma na celu zapobieganie rozprzestrzenianiu się chorobom zakaźnym oraz ochronę zdrowia publicznego.

$\mathrm{Z}$ tego punktu widzenia kwestią zasadniczą jest to, że w odniesieniu do szczepień ochronnych możliwe jest zastosowanie przymusu bezpośredniego i pośredniego ${ }^{27}$. Przymus bezpośredni zgodnie $\mathrm{z}$ art. 36 ust. 1 u.z.z.z.ch. w postaci przytrzymania, unieruchomienia lub przymusowego podania leków może być użyty wówczas gdy: osoba niepoddająca się obowiązkowemu szczepieniu jest podejrzana lub rozpoznano u niej chorobę szczególnie niebezpieczną i wysoce zakaźną stanowiącą bezpośrednie zagrożenie dla zdrowia lub życia innych osób. Oznacza to, zgodnie z powyższą analizą regulacji prawnych oraz stanowiskiem judykatury i poglądami doktryny, że jeżeli omawiane przesłanki nie zostaną spełnione, możliwe jest zastosowanie przymusu pośredniego ${ }^{28}$. Postępowanie $\mathrm{w}$ tym zakresie inicjowane jest przez lekarza, który zobowiązany jest do składania sprawozdań kwartalnych z wykonania szczepieńn ${ }^{29}$. Sprawozdanie takie przekazywane jest państwowemu powiatowemu inspektorowi sanitarnemu. W dziale drugim tego druku znajduje się rubryka, w której umieszcza się informację o liczbie osób uchylających się od obowiązku szczepień oraz dołącza imienny wykaz tych osób.

W kontekście powyższego, również odmowa wykonania szczepienia ochronnego przeciwko gruźlicy może skutkować także sankcjami karny-

26 Wyrok Sądu Najwyższego Izba Karna z dnia 8 stycznia 2016 r., V KK 306/15, LEX nr 1963649; wyrok Wojewódzkiego Sądu Administracyjnego w Białymstoku z dnia 16 kwietnia 2013 r., II SA/Bk 18/13, CBOSA.

27 Zob. W. Piątek, A. Skoczylas [w:] R. Hauser, A. Skoczylas (red.), Postępowanie egzekucyjne w administracji. Komentarz, Warszawa 2012, s. 142.

28 Zob. M. Paszkowska, Przymus medyczny stosowany w zapobieganiu i zwalczaniu chorób zakaźnych, „Przegląd Prawa Publicznego” 2009, nr 7/8, s. 107-119.

29 Zob. P. Daniel, Egzekucja obowiazku poddania małoletniego...., s. 49. 
$\mathrm{mi}^{30}$ na gruncie art. $115 \S 1$ Kodeksu wykroczeńn ${ }^{31}$ : kto, pomimo zastosowania środków egzekucji administracyjnej, nie poddaje się obowiązkowemu szczepieniu ochronnemu przeciwko gruźlicy lub innej chorobie zakaźnej albo obowiązkowemu badaniu stanu zdrowia, mającemu na celu wykrycie lub leczenie gruźlicy, choroby wenerycznej lub innej choroby zakaźnej, podlega karze grzywny do 1500 złotych albo karze nagany.

Ponadto należy wskazać, że kolejnym środkiem, który przysługuje lekarzowi jest powiadomienie sądu rodzinnego. Otóż zgodnie z art. 109 ust. 1 ustawy z dnia 25 lutego 1964 r. - Kodeks rodzinny i opiekuńczy ${ }^{32}$ jeżeli dobro dziecka jest zagrożone, sąd opiekuńczy wyda odpowiednie zarządzenia. Ponadto wykładnia systemowa i celowościowa nakazują przyjąć, że sąd opiekuńczy może zobowiązać rodziców małoletniego do określonego postępowania (art. 109 § 2 pkt 1 k.r.o.) albo poddać wykonanie władzy rodzicielskiej stałemu nadzorowi kuratora sądowego (art. $109 \S 2$ pkt 3 k.r.o.). W literaturze szeroko prezentowany jest pogląd, że zastosowanie tego środka jest jednak bardzo wątpliwe w praktyce ${ }^{33}$. Sądy musiałyby orzec o odebraniu przynajmniej czasowym władzy rodzicielskiej rodzicom w zakresie podejmowania decyzji o świadczeniach zdrowotnych wobec dziecka, co łączyłoby się z co najmniej okresowym odebraniem im dziecka spod opieki faktycznej.

A przecież niezwykle trudno byłoby udowodnić, że rodzice, którzy dbają o zdrowie i bezpieczeństwo dziecka, nie czynią tego w jego najlepiej pojmowanym interesie. Co więcej, należy dostrzec, że ostatecznym środkiem jest pozbawienie władzy rodzicielskiej. Jeżeli władza rodzicielska nie może być wykonywana z powodu trwałej przeszkody albo jeżeli rodzice nadużywają władzy rodzicielskiej lub w sposób rażący zaniedbują swe obowiązki względem dziecka, sąd opiekuńczy pozbawi rodziców władzy rodzicielskiej ${ }^{34}$. Pozbawienie władzy rodzicielskiej może być orzeczone także w stosunku do jednego z rodziców (art. $111 \S 1$ k.r.o.).

30 Zob. B. Kurzępa, Przestępstwa i wykroczenia określone w ustawie o zapobieganiu oraz zwalczaniu zakażeń i chorób zakaźnych u ludzi, „Prokuratura i Prawo” 2010, nr 10, s. 149-159.

31 Ustawa z dnia 20 maja 1971 r. - Kodeks wykroczeń, tekst jednolity: Dz. U. z 2019 r. poz. 821 z późn. zm.

32 Ustawa z dnia 25 lutego 1964 r. - Kodeks rodzinny i opiekuńczy, tekst jednolity: Dz. U. z 2017 r. poz. 682 z późn. zm. (dalej: k.r.o.).

33 Zob. M. Boratyńska, Szczepienia ochronne małoletnich a wykonywanie władzy rodzicielskiej. Uwagi na tle wyroku NSA, „Prawo i Medycyna” 2013, nr 3/4, s. 74 i nast.

34 J. Ignaczewski [w:] J. Ignaczewski (red.), Wtadza rodzicielska i kontakty $z$ dzieckiem. Komentarz, Warszawa 2012, s. 168 i nast. 


\section{Podsumowanie}

Analiza odmowy wykonania obowiązku poddania dziecka obowiązkowi szczepień ochronnych skłania do sformułowania następujących wniosków. Po pierwsze, obowiązek ustawowy poddania dziecka szczepieniu ochronnemu powinien zawsze stanowić priorytet. Po drugie natomiast, odmowę poddania dziecka szczepieniu ochronnemu jako wyjątek mogą uzasadniać jedynie przeciwskazania zdrowotne. Po trzecie, to $\mathrm{w}$ interesie przedstawicieli ustawowych oraz opiekunów prawnych i faktycznych dzieci, powinny znajdować się przesłanki przemawiające za koniecznością wykonania szczepienia ochronnego u dzieci. Po czwarte, ratowanie zdrowia, a niejednokrotnie życia dzieci, poprzez wykonanie szczepienia ochronnego, zawsze musi być traktowane jako cel i środek o pierwszoplanowym działaniu. Tylko kształtowanie takiej świadomości i odpowiedzialnych postaw poprzez właściwą edukację może przynieść dużo korzystniejsze efekty. Natomiast użycie środków egzekucji administracyjnej oraz środków karnych zawsze powinno pozostać ostateczną metodą.

Słowa kluczowe: szczepienie ochronne, obowiązek ustawowy, dziecko

\section{Bibliografia}

\section{Źródła prawa}

Ustawa z dnia 25 lutego 1964 r. - Kodeks rodzinny i opiekuńczy, tekst jednolity: Dz. U. z 2017 r. poz. 682 z późn. zm.

Ustawa $\mathrm{z}$ dnia 17 czerwca $1966 \mathrm{r}$. o postępowaniu egzekucyjnym w administracji, tekst jednolity: Dz. U. z 2019 r. poz. 1348 z późn. zm.

Ustawa z dnia 20 maja 1971 r. - Kodeks wykroczeń, tekst jednolity: Dz. U. z 2019 r. poz. 821 z późn. zm.

Ustawa z dnia 6 września 2001 r. - Prawo farmaceutyczne, tekst jednolity: Dz. U. z 2019 r. poz. 499 z późn. zm.

Ustawa z dnia 6 listopada 2008 r. o prawach pacjenta i Rzeczniku Praw Pacjenta, tekst jednolity: Dz. U. z 2019 r. poz. 1127 z późn. zm.

Ustawa z dnia 5 grudnia 2008 r. o zapobieganiu oraz zwalczaniu zakażeń i chorób zakaźnych u ludzi, tekst jednolity: Dz. U. z 2019 r. poz. 1239. 
Rozporządzenie Ministra Zdrowia z dnia 21 grudnia 2010 r. w sprawie niepożądanych odczynów poszczepiennych oraz kryteriów ich rozpoznawania, Dz. U. z 2010 r. Nr 254, poz. 1711.

Rozporządzenie Ministra Zdrowia z dnia 18 sierpnia 2011 r. w sprawie obowiązkowych szczepień ochronnych, tekst jednolity: Dz. U. z 2018 r. poz. 753.

\section{Orzecznictwo}

Wyrok Sądu Najwyższego z dnia 8 stycznia 2016 r., V KK 306/15, LEX nr 1963649. Wyrok Naczelnego Sądu Administracyjnego z dnia 1 sierpnia 2013 r., II OSK 745/12, Centralna Baza Orzeczeń Sądów Administracyjnych (CBOSA).

Wyrok Wojewódzkiego Sądu Administracyjnego w Białymstoku z dnia 1 lutego 2011 r., II SA/BK 723/10, Legalis nr 339506.

Wyrok Wojewódzkiego Sądu Administracyjnego w Krakowie z dnia 26 kwietnia 2012 r., III SA/Kr 901/11, CBOSA.

Wyrok Wojewódzkiego Sądu Administracyjnego w Białymstoku z dnia 16 kwietnia 2013 r., II SA/Bk 18/13, CBOSA.

Wyrok Wojewódzkiego Sądu Administracyjnego w Poznaniu z dnia 11 września 2013 r., II SA/Po 711/13, CBOSA.

Wyrok Wojewódzkiego Sądu Administracyjnego w Warszawie z dnia 19 października 2016 r., VII SA/Wa 2539/15, LEX nr 2159949.

Wyrok Wojewódzkiego Sądu Administracyjnego w Warszawie z dnia 19 października 2016 r., VII SA/Wa 2541, CBOSA.

Wyrok Wojewódzkiego Sądu Administracyjnego w Warszawie z dnia 5 kwietnia 2017 r., VII SA/Wa 301/17, CBOSA.

\section{Literatura}

Augustynowicz A., I. Wrześniewska-Wal, Aspekty prawne obowiązkowych szczepień ochronnych u dzieci, „Pediatria Polska” 2013, t. 88, s. 120-126.

Boratyńska M., Szczepienia ochronne małoletnich a wykonywanie władzy rodzicielskiej. Uwagi na tle wyroku NSA, „Prawo i Medycyna” 2013, nr 3/4, s. 68-88.

Daniel P., Egzekucja obowiązk poddania małoletniego dziecka szczepieniu ochronnemu w orzecznictwie sądów administracyjnych, "Przegląd Prawa Publicznego" 2014, nr 4, s. 45-55.

Gajdzińska-Ożóg K., M. Ożóg, Zgłaszanie niepożądanych odczynów poszczepiennych $w$ świetle ustawy z 5 grudnia 2008 r. o zapobieganiu oraz zwalczaniu zakażeń $i$ chorób zakaźnych u ludzi, "Przegląd Prawa Publicznego" 2010, nr 6, s. 42-49.

Gałecki S., Szczepienia obowiązkowe - wolność jednostki a bezpieczeństwo społeczności, „Medycyna Praktyczna. Szczepienia” 2014, nr 3, s. 87-90.

Ignaczewski J. [w:] J. Ignaczewski (red.), Wtadza rodzicielska i kontakty z dzieckiem. Komentarz, Warszawa 2012, s. 154-189. 
Jaworska I., Odmowa zaszczepienia dziecka i jej konsekwencje prawne, „Przegląd Prawa Publicznego" 2017, nr 3, s. 60-72.

Kubiak R., Szczepienia dzieci bez obecności rodziców, „Medycyna Praktyczna. Szczepienia" 2012, nr 2, s. 80-81.

Kurzępa B., Przestępstwa i wykroczenia określone w ustawie o zapobieganiu oraz zwalczaniu zakażeń $i$ chorób zakaźnych u ludzi, „Prokuratura i Prawo” 2010, nr 10, s. 149-159.

Ożóg M., System handlu produktem leczniczym i produktami pokrewnymi. Problematyka prawna, Warszawa 2010.

Paszkowska M., Przymus medyczny stosowany w zapobieganiu i zwalczaniu chorób zakaźnych, „Przegląd Prawa Publicznego" 2009, nr 7/8, s. 107-119.

Piątek W., A. Skoczylas, [w:] R. Hauser, A. Skoczylas (red.), Postępowanie egzekucyjne w administracji. Komentarz, Warszawa 2012.

Radlak K., Ograniczenie konstytucyjnych wolności i praw obywatela a obowiazek szczepień w świetle projektu ustawy o zmianie ustawy o zapobieganiu oraz zwalczaniu zakażeń i chorób zakaźnych u ludzi oraz niektórych innych ustaw z 27.10.2017 r., „Przegląd Prawa Publicznego" 2018, nr 5, s. 27-44.

\section{REFUSAL TO FULFIL A DUTY TO VACCINATE A CHILD}

\section{Summary}

Pursuant to the Act of 05.12.2008 on prevention and combating infections and contagious diseases in people, children's legal representatives and actual guardians are responsible for fulfilment of the vaccination duty. Protective vaccination is a legal duty and only a doctor carrying out qualification tests has the right to decide about vaccination of a child. Only medical contraindications can justify a refusal to vaccinate a child in exceptional cases. Failure to fulfil the vaccination duty results in administrative and penal consequences. The obligation to vaccinate a child follows from legal regulations. Thus, it is assumed that there is no need to issue an administrative decision and failure to take action shall have legal consequences.

Key words: protective vaccination, legal duty, child 


\section{ОТКАЗ ОТ ИСПОЛНЕНИЯ ОБЯЗАТЕЛЬСТВА ПО ИММУНИЗАЦИИ РЕБЕНКА}

\section{Резюме}

Уставные и фактические опекуны несут ответственность за реализацию плана профилактической вакцинации детей на основании Закона от 5.12.2008 г. о профилактике и борьбе с инфекциями и инфекционными заболеваниями у людей. Защитная вакцина является законным обязательством, и только лицо, которое выполнит квалификационный тест, имеет право принять решение о вакцинации ребенка. Отказ от предоставления ребенку защитной вакцинации в качестве исключения может оправдать противопоказания для здоровья. Невыполнение прививок приводит к административным и уголовным последствиям. Обязательство подвергать ребенка защитным прививкам вытекает из положений закона. Следовательно, предполагается, что нет необходимости принимать административное решение, а отказ от принятия мер будет иметь правовые последствия.

Ключевые слова: защитная вакцинация, законное обязательство, ребенок 
